\title{
Pendampingan Guru TK/PAUD dalam Pembuatan Media Pembelajaran Interaktif Berbasis Powtoon dan Microsoft Office Powerpoint
}

Tijaniyah $^{1}$, Feri Febriyanto ${ }^{2}$, Fahmi Dinillah ${ }^{3}$

Universitas Nurul Jadid, Probolinggo ${ }^{1,2,3}$

\{tijaniyah@unuja.ac.id ${ }^{1}$, ferifeb@gmail.com $^{2}$, fahmidinillah201@gmail.com $^{3}$ \}

\author{
Submission: 2021-04-07 Received: 2021-04-29 Published: 2021-04-30
}

\section{Keywords: \\ Training, \\ Powtoon, \\ Teacher}

\begin{abstract}
The Covid 19 pandemic period with community service in the form of training for PAUD kindergarten teachers in Paiton Probolinggo sub-district in making interactive learning media using powtoons and powerpoints is very useful to help teachers provide learning material online so that students don't get bored learning at home. The material is also varied and interactive which is useful to attract the enthusiasm of the students to study harder.
\end{abstract}

Katakunci:

Pelatihan, Powtoon, Gur.

\begin{abstract}
Abstrak. Masa Pendemi Covid 19 dengan adanya pengabdian kepada masyarakat berbentuk pelatihan untuk para guru TK PAUD sekecamatan Paiton Probolinggo dalam pembuatan media pembelajaran interaktif menggunakan powtoon dan powerpoint sangat bermanfaat membantu para guru memberikan materi pembelajaran secara daring sehingga para murid tidak bosan belajar dirumah. Materinya pun beragam dan interaktif yang bermanfaat untuk menarik antesi para murid untuk lebih giat belajar.
\end{abstract}

\section{Pendahuluan}

Pandemi Covid-19 membuat siswa harus belajar dari rumah. Agar kegiatan belajar dari rumah menjadi berkualitas, guru bisa menerapkan pembelajaran dalam jaringan (Daring) dengan menggabungkan beberapa model pembelajaran (Sidik. 2020).

Dalam menyampaikan pesan atau informasi, khususnya dalam proses pembelajaran Daring diperlukan adanya media dan alat bantu pembelajaran yang akan mengefektifkan tercapainya tujuan pembelajaran. Dalam pendidikan, media berfungsi sebagai sarana fisik penyampaian materi, dan pembawa pesan. Oleh karena media online yang dapat digunakan sangat 
beragam, maka pendidik perlu menguasai Media pembelajaran online dalam kegiatan pembelajarannya. (Sidik.2020)

Kebanyakan guru di kecamatan Paiton Probolinggo menggunakan media pembelajaran secara konvensional, banyak sekolah yang libur dikarenakan masa pandemi covid 19. Kendala yang dihadapi oleh para guru dalam membuat media pembelajaran interaktif berbasis online khususnya di Kecamatan Paiton Kabupaten Probolinggo adalah kurangnya pemahaman tentang informasi pembuatan media pembelajaran interaktif, tidak ada fasilitas komputer dalam membuat media pembelajaran kurangnya fasilitas internet di sekolah ah dan banyaknya aplikasi media pembelajaran sehingga para guru merasa kebingungan dalam memilih media pembelajaran yang tepat untuk menarik atensi siswa khususnya siswa TK dan PAUD. Untuk meningkatkan efektivitas pendidikan kan di taman kanak-kanak dan PAUD se Kecamatan Paiton Kabupaten Probolinggo maka mahasiswa unuja dalam program KKN berbasis karya ilmiah mengadakan sebuah pendampingan pembuatan media pembelajaran interaktif menggunakan aplikasi terbaru yaitu PowToon dan PowerPoint.

Ragam aplikasi potensial untuk dimanfaatkan guru sebagai media pembelajaran dan menarik atensi siswa dalam belajar online atau daring, salah satu aplikasi tersebut adalah PowToon dan PowerPoint kedua aplikasi ini seringkali digunakan oleh para guru sebagai media pembelajaran daring. Adapun kelebihan aplikasi PowToon adalah interaktif, kolaboratif, variatif dan unik.

Aplikasi Powtoon merupakan aplikasi terhubung internet atau web apps online yang dapat menyajikan presentasi atau paparan materi. Tampilannya berupa video yang berisi berbagai animasi-animasi yang dapat menarik atensi siswa didik. Kholilurrohmi (2017). Video animasi dapat menghindarkan salah pengertian pada proses belajar tersebut sehingga siswa didik dapat sepenuhnya menerima dan memahami materi, pikiran, dan pesan yang telah dirancang guru (Anita.2016).

Adapun pengabdian masyarakat berbentuk pendampingan kepada para guru TK dan PAUD dalam pembuatan media pembelajaran interaktif berbasis online ini memiliki rumusan masalah yaitu:

a. Bagaimana membantu guru untuk mempelajari aplikasi powtoon dan powerpoint sebagai media pembelajaran interaktif. 
b. Bagaimana memfasilitasi guru komputer, jaringan internet serta pelatihan pembuatan media pembelajaran interaktif

Pengabdian masyarakat ini juga memiliki batasan masalah yaitu:

a. Aplikasi media pembelajaran menggunakan powtoon dan MS. powerpoint.

b. Target subjek adalah guru TK dan PAUD.

c. Lokasi target PKM adalah sekolah TK PAUD sekecamatan paiton kabupaten probolinggo.

d. Jumlah peserta adalah 20 peserta dari perwakilan sekolah TK PAUD sekecamatan paiton probolinggo

\section{Metode}

Pengabdian Kepada Masyarakat (PKM) yang dilaksanakan oleh mahasiswa prodi teknik elektro yaitu melakukan pendampingan untuk guru TK PAUD dalam pembuatan media pembelajaran interaktif menggunakan powtoon dan microsoft power point. Program PKM yang terlaksana pada tanggal 31 Januari 2021, bertempat di laboratorium komputer fakultas teknik universitas nurul jadid. Hal ini dapat di lihat pada Gambar 1 peta Universitas

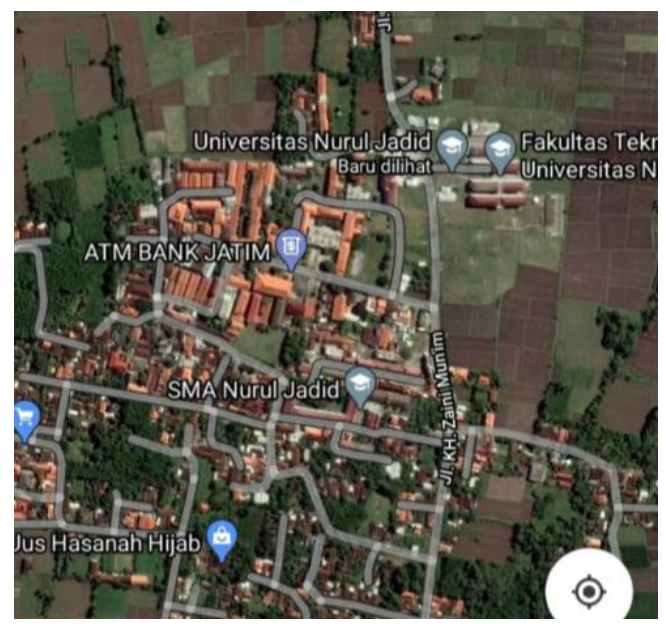


Gambar 1. Peta Universitas Nurul Jadid

Adapun alur proses pelaksanaan PKM oleh mahasiswa prodi teknik elektro fakultas teknik universitas nurul jadid sebagaimana dijelaskan pada Gambar 2 dibawah ini (Eric. 2018):

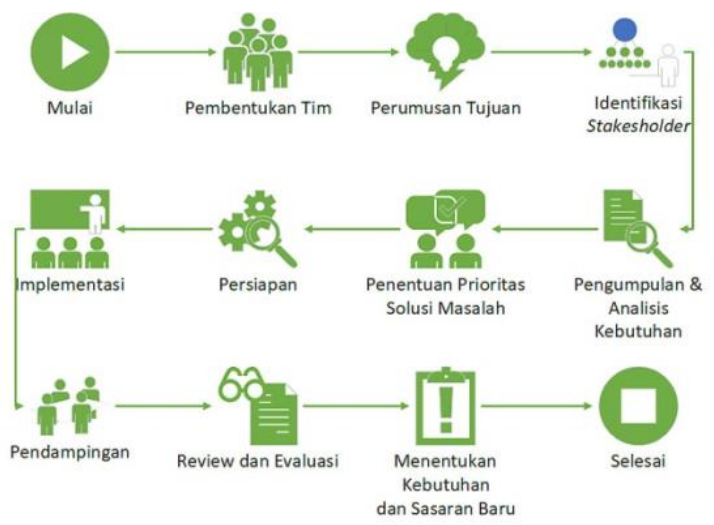

Gambar 2. Alur Pengabdian Kepada Masyarakat (Eric.2018)

Awal pelaksanaan PKM oleh mahasiswa universitas nurul jadid paiton probolinggo adalah membentuk tim PKM yang terdiri dari 9 mahasiswa aktif. Kemudian mulai menentukan tujuan, identifikasi stakesholder, pengumpulan serta analisa kebutuhan PKM seperti ketersediaan laboratorium komputer fakultas teknik dan jaringan internet. Lalu menentukan masalah dan solusi, proses persiapan pelatihan pembuatan media pembelajaran seperti mempersiapkan modul pelatihan, sertifikat dan lain lain. Tahap implementasi acara pelatihan yang dilaksanakan di laboratorium komputer dan sekaligus dilakukan pendampingan oleh masing-masing mentor seperti mentor pelatihan menggunakan aplikasi powtoon yaitu Ibu Tijaniyah selaku dosen pembimbing KKN 2021, Mohammad Firdaus selaku Koordinator Tim KKN serta Feri Febriyanto dan Muhammad Fikri Maula selaku Anggota Tim KKN. Setelah terlaksananya acara PKM dalam bentuk pelatihan untuk guru TK PAUD maka dilaksanakanlah tahap evaluasi serta solusi dari permasalahan selama acara berlangsung

\section{Hasil}

Pengabdian kepada masyarakat ini telah dialaksanakan oleh mahasiswa prodi teknik elektro fakultas teknik universitas nurul jadid paiton probolinggo pada tanggal 31 Januari 2021 bertempat dilaboratorium komputer fakultas 
teknik. PKM ini berbentuk pelatihan pembuatan media pembelajaran interaktif untuk guru TK PAUD sekecamatan Paiton Kabupaten Probolinggo yang terdiri dari TK PAUD Masyitoh Mambaul Ulum, TK Bina Anaprasa, RA Perwanida III, PAUD Cerdas Mulia, TK Anak Sholeh. TK KB Insan Terpadu dan TK KB Al-Fatih.

Pelaksanaan KKN tahun 2021 yang dibimbing oleh Ibu Tijaniyah ini menghasilkan beberapa output diantara nya : karya ilmiah jurnal terakreditasi sinta 5 dan jurnal terakreditasi ISSN, sebuah modul pelatihan, sertifikat, video tutorial pembuatan media pembelajaran menggunakan powtoon dan microsoft office power point. Berikut ini adalah hasil dari pengabdian kepada masyarakat berupa pendampingan pelatihan pembuatan media pembelajaran interaktif untuk para guru TK PAUD.

Poster produk hasil PKM merupakan salah satu kebutuhan terpenting dalam menunjang keberhasilan sebuah Pengabdian Kepada Masyarakat, beriktu ini poster produk hasil PKM dapat dilihat pada link berikut https://web.facebook.com/photo?fbid=158916606001145\&set=a. 1101854042075 99. Selain itu ada beberapa video kegiatan dan tutorial pelatihan juga dapat dilihat pada link youtube ini https://youtu.be/5V tmbfc2aM (KKNJAYA OFFICIAL). berikut ini Gambar 3 adalah salah satu foto kegiatan bersama para guru perwakilan sekolah TK PAUD sekecamatan Paiton.

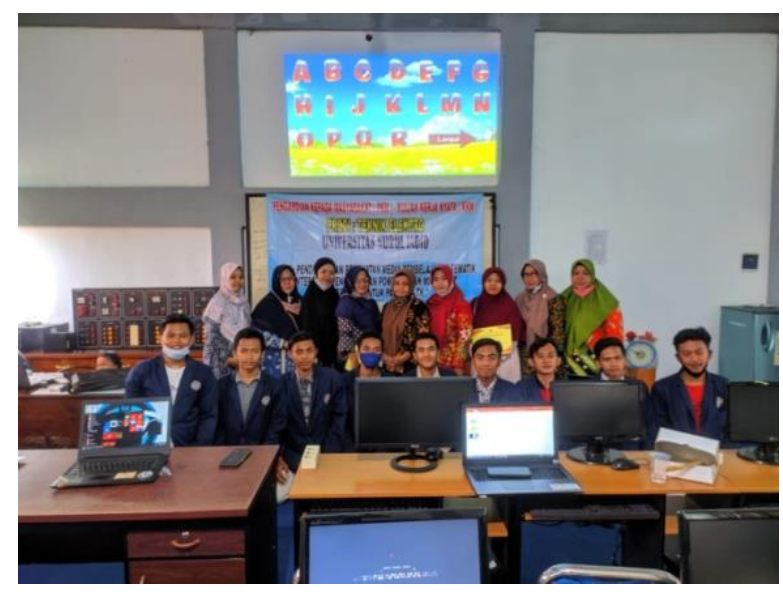

Gambar 3. Foto Bersama Para Guru 


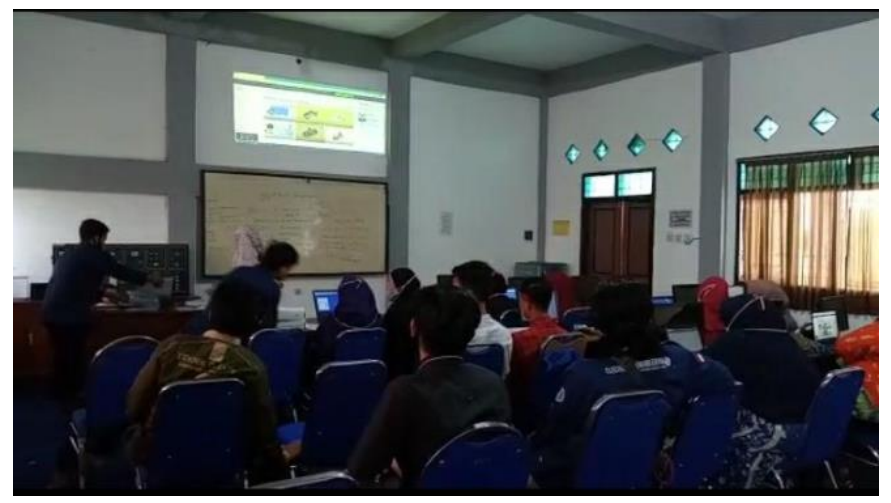

Gambar 4. Foto Kegiatan Pelatihan

\section{Pembahasan}

Media pembelajaran "Powtoon" merupakan layanan online untuk membuat sebuah paparan yang memiliki fitur animasi sangat menarik diantaranya animasi tulisan tangan, animasi kartun, dan efek transisi yang lebih hidup serta pengaturan time line yang sangat mudah. Berikut beberapa Gambar 5 dan 6 aplikasi powtoon.

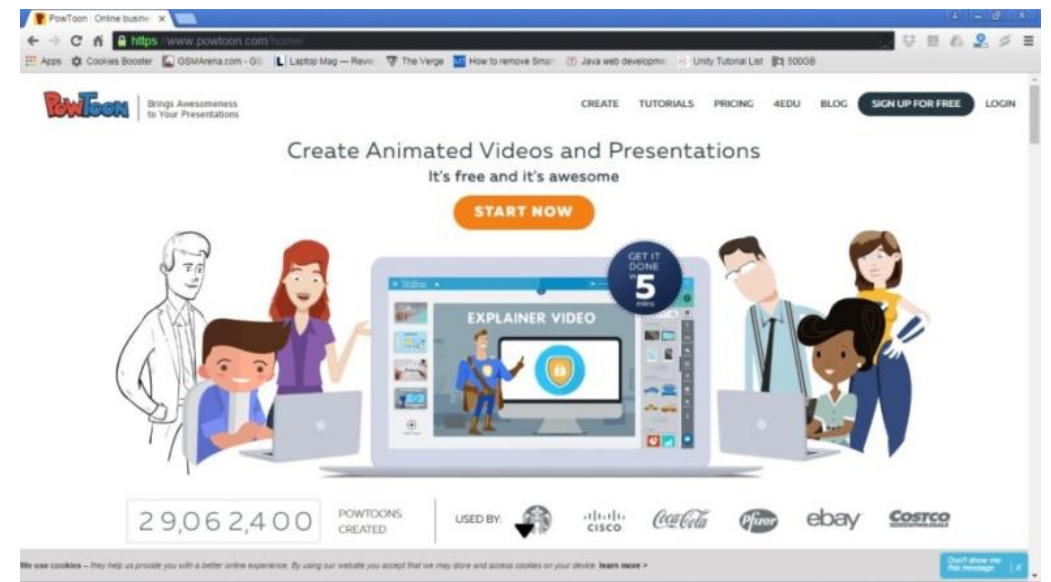

Gambar 5. Aplikasi Powtoon 


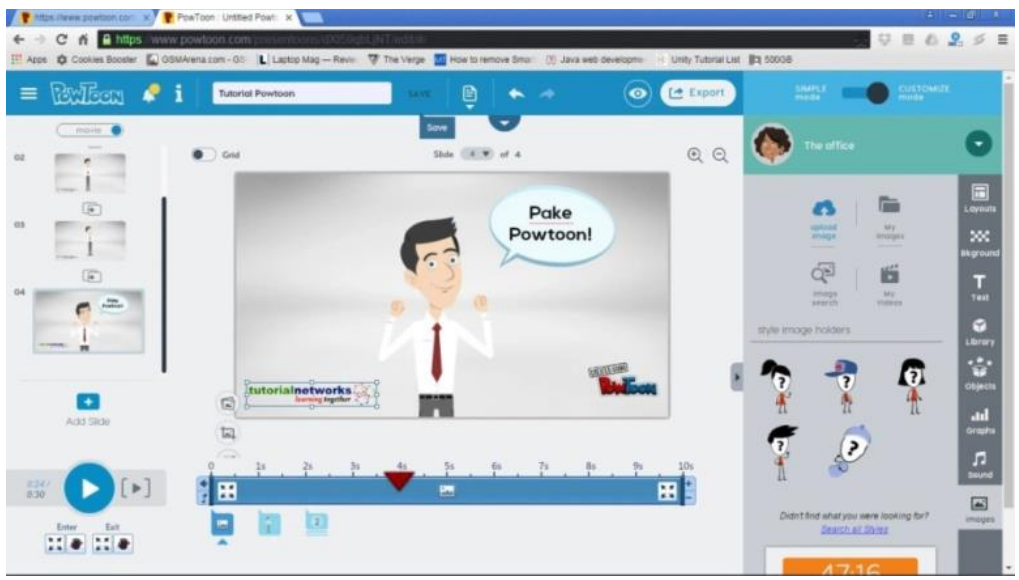

Gambar 6. Aplikasi Powtoon

\section{Kesimpulan}

Pengabdian kepada masyarakat berbentuk pendampingan pelatihan untuk para guru dalam pembuatan media pembelajaran interaktif ini sangat berguna untuk guru dan murid. Guru dapat memberikan materi pembelajaran yang menyenangkan serta interaktif secara daring sehingga para murid tidak jenuh dan bosan belajar dirumah. Aplikasi powtoon dan powetpoint sangat mudah digunakan dan para guru bisa cepat memahami materi pelatihan.

\section{Pengakuan}

Ucapan terimakasih kami segenap tim KKN tahun 2021 kepada : Allah SWT yang telah memberi kita rahmat dan kesehatan sehingga dapat melaksanakan pengabdian kepada masyarakat ini dengan lancar, Pengasuh Pondok Pesantren Nurul Jadid KH.Zuhri Zaini, Rektor Universitas Nurul Jadid KH. Abdul Hamid Wahid, Bapak Ahmad Fawaid selaku Kepala LP3M Universitas Nurul Jadid, Bapak Kamil Malik selaku Dekan Fakultas Teknik dan seluruh mahasiswa Fakultas Teknik Universitas Nurul Jadid.

\section{Referensi}

Anita, S. (2016). Pengembangan Media Pembelajaran Teks Anekdot Berbasis Animasi Pada Siswa Kelas X Sekolah Menengah Kejuruan, Tesis. Lampung: Program Magister Pendidikan Bahasa Indonesia Univ. Bandar Lampung. 
Ariyanto, R., Kantun, S., \& Sukidin, S. (2018). Penggunaan Media Powtoon Untuk Meningkatkan Minat Dan Hasil Belajar Siswa Pada Kompetensi Dasar Mendeskripsikan Pelaku-Pelaku Ekonomi Dalam Sistem Perekonomian Indonesia. JURNAL PENDIDIKAN EKONOMI: Jurnal IImiah IImu Pendidikan, IImu Ekonomi Dan IImu Sosial, 12(1), 122. https://doi.org/10.19184/jpe.v12i1.7622

eric kunto wibowo. (2018). metode pelaksanaan pengabdian kepada masyarakat. diakses pada tgl 6 April 2021. https://figshare.com/articles/figure/Metode_Pelaksanaan_Pengabdi an_kepada_Masyarakat/7011266/1.

Kholilurrohmi, I. (2017). Efektivitas Penerapan Media Pembelajaran Video Powtoon Pada Mata Pembelajaran Kimia Terhadap Motivasi dan Prestasi Belajar Peserta Didik Kelas X Semeseter 1 SMAN 1 Plere, Skripsi. Yogyakarta.

Sidik. 15 juli 2020.Pembuatan Media Pembelajaran Berbasis Online. Diakses tanggal 06 April 2021. https://harbundpurwokerto.sch.id/pelatihan-pembuatanmedia-pembelajaran-berbasis-online/ 